BISMA

(Bisnis dan Manajemen)
Volume 13, Issue 1, 2020, 26-36

ISSN 2549-7790 (Online)

DOI: 10.26740/bisma.v13n1.p26-37

https://journal.unesa.ac.id/index.php/bisma/index

\title{
Service quality and store atmosphere on customer satisfaction and repurchase intention
}

\author{
Santirianingrum Soebandhi $^{1 *}$, Abdul Wahid ${ }^{2}$, Ira Darmawanti ${ }^{3}$ \\ ${ }^{1}$ Universitas Wijaya Kusuma Surabaya, Indonesia \\ ${ }^{2}$ Universitas Narotama, Indonesia \\ ${ }^{3}$ University of Vienna, Austria
}

\begin{abstract}
Nowadays, consumers are not only looking for good tastes, but they are also looking for a cosy cafe atmosphere and satisfying service. The high competition in the culinary business has forced entrepreneurs to offer different concepts to attract customers. This study will give an account of analyzing the role of cafe atmosphere, service quality and customer satisfaction in customer purchase intention in thematic cafe in Surabaya. This study involved 150 respondents with PLS-SEM was used to analyze the data. The analysis shows that all of the hypotheses proposed are supported. The results of this study also present that, compared to service quality, the cafe atmosphere has a stronger effect on customer satisfaction, leading to repurchase intention of the customers.
\end{abstract}

Keywords: cafe atmosphere; service quality; customer satisfaction; repurchase intention; thematic cafe

Received: March 30, 2020; Accepted: July 07, 2020; Published: October 31, 2020

*Corresponding author

Email: santirianingrum@uwks.ac.id

\section{To cite this document:}

Soebandhi, S., Wahid, A., \& Darmawanti, I. (2020). Service quality and store atmosphere on customer satisfaction and repurchase intention. BISMA (Bisnis dan Manajemen), 13(1), 26-36. https://doi.org/10.26740/bisma.v13n1.26-37.

\section{INTRODUCTION}

In Indonesia, food service market has been growing rapidly. According to the Market Access Secretariat Global Analysis Report (2016), Indonesia has been categorized as the fastest growing country among all ASEAN countries. Food service market in Indonesia is varied, from hotel and restaurant serving local and international food to kiosk or food stall and food stand selling food in the road. This business growth is in line with the growth of tourist and middleclass population (Mordor Intelligence, 2018). In Indonesia, restaurant, fast-food restaurant, cafe, and food stand becomes the main impetus of culinary business growth (Market Access Secretariat Global Analysis Report, 2016; Mordor Intelligence, 2018). 
Soebandhi, S., Wahid, A., \& Darmawanti, I.

Service quality and store atmosphere on customer satisfaction and repurchase intention

Surabaya as the second biggest city in Indonesia also shows a significant growth of the culinary business. Recently, many entrepreneurs have opened cafe business with various concepts or ideas to attract customers from a diverse background. It is because the local government facilitates licensing to set up a business. Indonesia Cafe and Restaurant Association (Apkrindo) states that restaurant growth in Surabaya is almost $20 \%$ per year (JPNN, 2018). This high competition makes that the cafe business players thinking the strategy to win the competition.

The more cafe offering different concepts, the more choices for consumers are available. Here, business people should be able to prepare a good strategy to satisfy customers. One of these strategies is making a good service and atmosphere for the customers. Consumers are not only searching for a good taste of the food but also looking for the experience through cafe atmosphere and good quality of service. Combined of the three enable to satisfy consumers and make them do repurchase in the future (Ryu, Lee, \& Kim, 2012).

Table 1. Value Sales and Growth of Indonesia's Foodservice by Subsector (in US\$ millions)

\begin{tabular}{lccccccc}
\multicolumn{1}{c}{ Subsector } & \multirow{2}{*}{2013} & \multirow{2}{*}{2014} & \multirow{2}{*}{$2015^{\mathrm{E}}$} & \multirow{2}{*}{$2016^{\mathrm{F}}$} & $2019^{\mathrm{F}}$ & $\begin{array}{c}\text { \%CAGR } \\
2010-14\end{array}$ & $\begin{array}{c}\text { \% CAGR } \\
2015^{\mathrm{E}}-19^{\mathrm{F}}\end{array}$ \\
\hline Total consumer & $33,625.9$ & $36,814.8$ & $39,906.4$ & $43,310.8$ & $56,290.7$ & 8.7 & 9.0 \\
Foodservice & & & & & & & \\
Full-service restaurant & $27,486.2$ & $30,022.8$ & $32,465.4$ & $35,152.5$ & $45,423.5$ & 8.5 & 8.8 \\
Cafes/ bars & $3,298.6$ & $3,634.9$ & $3,969.0$ & $4,338.8$ & $5,756.0$ & 9.4 & 9.7 \\
Fast food & $1,422.8$ & $1,651.3$ & $1,861.1$ & $2,092.8$ & $2,941.5$ & 12.7 & 12.1 \\
Street stalls/ kiosks & $1,203.6$ & $1,291.9$ & $1,376.4$ & $1,468.7$ & $1,821.1$ & 6.3 & 7.2 \\
Pizza consumer & 356.8 & 411.9 & 474.2 & 542.5 & 755.1 & 11.6 & 12.3 \\
$\begin{array}{l}\text { Foodservice* } \\
\text { Self-service cafetarias }\end{array}$ & 179.9 & 196.8 & 211.7 & 228.1 & 288.9 & 8.9 & 8.1 \\
100\% home delivery/ & 14.9 & 17.1 & 22.8 & 29.8 & 59.8 & 57.2 & 27.3 \\
takeaway & & & & & & \\
\hline
\end{tabular}

*Note: Pizza consumer foodservice is including three sub-sectors (pizza fast food, full-service restaurant, and pizza $100 \%$ home delivery/ takeaway). These sub-sectors are already included in the total fast food, total fullservice restaurant and total $100 \%$ home delivery/ takeaway sectors. Thus, pizza consumer foodservice is not included in the total consumer foodservice value sales. F: Forecast, E: Estimated, CAGR: Compound Annual Growth Rate.

Source: Market Access Secretariat Global Analysis Report (2016)

In the marketing context, the ambience or atmosphere of cafe is an essential aspect of how the consumers view every single service provided (Lin, 2009). Cafe atmosphere relies on the premise that the environment of the cafe (such as room layout, colour, lighting, and decoration) can stimulate the perception response and consumer emotion, in which, in the end, it affects the purchase behaviour (Berman \& Evans, 2013; Sirgy, Grewal, \& Mangleburg, 2000). Further, if this cafe atmosphere can be managed effectively, it might become a competitive advantage for the company (Keyt, Yavas, \& Riecken, 1994). By this means, the favourable and innovative ambience is paramount importance for the company succeeds.

Similar to the cafe atmosphere, service quality, according to Parasuraman, Zeithaml, \& Berry (1988) is a comparison between consumer's expectation of provided service and perceived service. The goal of business is to create customer satisfaction, leading to the increase of company and customers relationship, creating the positive response in the form of repurchase, creating customer loyalty, and suggesting other consumers to purchase the same 
product (Alma, 2011; Schnaars, 1991; Soriano, 2002). It means that the better service provided, it will create customer satisfaction and the satisfied customer is not easy to move on to other cafes (Kristiana \& Edwar, 2017). Thus, customer satisfaction becomes a key concept in marketing, especially in the service industry (Heung \& Gu, 2012).

Considering the gaps that research on consumer behaviour intentions have shown various results, this study is intended to analyze the role of cafe atmosphere and service quality in customer satisfaction and purchase intention in the context of thematic cafes in Surabaya.

\section{The Role of Cafe Atmosphere on Customer Satisfaction and Repurchase Intention}

Cafe atmosphere is a physical characteristic used to create an impression and to attract customer. Atmosphere or ambience is an important component of a shop or cafe because it can give a dominant sensory effect from the design of the shop or cafe (Berman \& Evans, 2013; Cox \& Brittain, 2004).

The atmosphere or ambience to design a cafe environment to produce an emotional effect in the consumer that enhance his purchase probability (Kotler, 1973). This designed atmosphere enables to influence the subjective feeling of the consumer and influence the satisfaction and purchase intention (Babin \& Attaway, 2000; Sirgy et al. 2000). Previous studies in the context of restaurant suggest the significant relationship between the atmosphere and customer satisfaction such as Heung \& Gu (2012), Kristiana \& Edwar (2017). Meanwhile, this concept has recently been challenged by Andaleeb \& Conway (2006) study demonstrating the opposite, that is, the atmosphere does not have a significant impact on customer satisfaction.

Although the cafe atmosphere is believed as the predictor that makes the consumer back and repeat purchase, the previous studies dealing with the effect of cafe atmosphere on repurchase intention shows the various result. Some studies confirm that a pleasing cafe atmosphere can encourage the consumer to come back again to the cafe (Ha \& Jang, 2012; Soriano, 2002). However, Chang (2000) and Namkung \& Jang (2007) studies offer contradictory findings. The direct effect of the atmosphere on behaviour intention is absence. H1: Cafe atmosphere positively influences customer satisfaction.

H2: Cafe atmosphere positively influences repurchase intention.

\section{The Role of Service Quality on Customer Satisfaction and Repurchase Intention}

Service quality is an attempt to fulfil the need and desire of the consumer to meet consumer satisfaction (Tjiptono \& Chandra, 2013). It may need to be taken into account since it becomes a basis for the company to create a long-term relationship with the consumer that makes the consumer will not move on to other places (Han \& Hong, 2005; Venetis \& Ghauri, 2004). A good service is also an indication to boost consumer satisfaction (Kristiana \& Edwar, 2017; Tambunan \& Suryawardani, 2015). However, research conducted by Laroche et al. (2004) showed interesting results. In their research, the relationship between service quality and customer satisfaction can be inversely related due to cultural influences.

Good service quality also enables the consumer to do repeat purchase. The study conducted by Baker \& Crompton (2000), in the tourism context, showed that commitment to re-use a service and willingness to overpay the service is influenced by the service delivered. Similar to that, Nietos et al. (2015), in the recreation context, also confirmed the same thing. 
Service quality and store atmosphere on customer satisfaction and repurchase intention

Notwithstanding, in the banking context, a study conducted by Tan (2019) shows a weak relationship between the two variables.

H3: Service quality positively influences customer satisfaction.

H4: Service quality positively influences repurchase intention.

\section{The Role of Customer Satisfaction on Repurchase Intention}

An individual's attitude or behaviour is influenced by psychological aspects, called intention (Söderlund \& Vilgon, 1999). To understand consumer behaviour, measuring the purchase intention is an effective way to predict the consumer behaviour in the future in repeat purchasing and recommending the service to others (Byon, Zhang, \& Baker, 2013). Repurchase intention is a behaviour attributable to past behaviour that directly influences an intention to repeat consuming in the future (Hasan, 2013). Repeat purchasing is also an action done more than once because consumers are satisfied with the services delivered (Peter \& Olson, 2010).

The previous studies related to satisfaction and purchase intention shows various results. In their thorough study of satisfaction and repurchase intention, Haemoon (2000), Han, Back, \& Barrett (2009), and Zhang \& Prasongsukarn (2017) were able to show that there is a positive relationship between customer satisfaction and repeat purchase intention. However, some studies also show a weak or even no significant relationship between customer satisfaction and repeat purchase intention (Chow et al., 2007; Kivela, Inbakaran, \& Reece, 2000).

H5: Customer satisfaction positively influences repurchase intention.

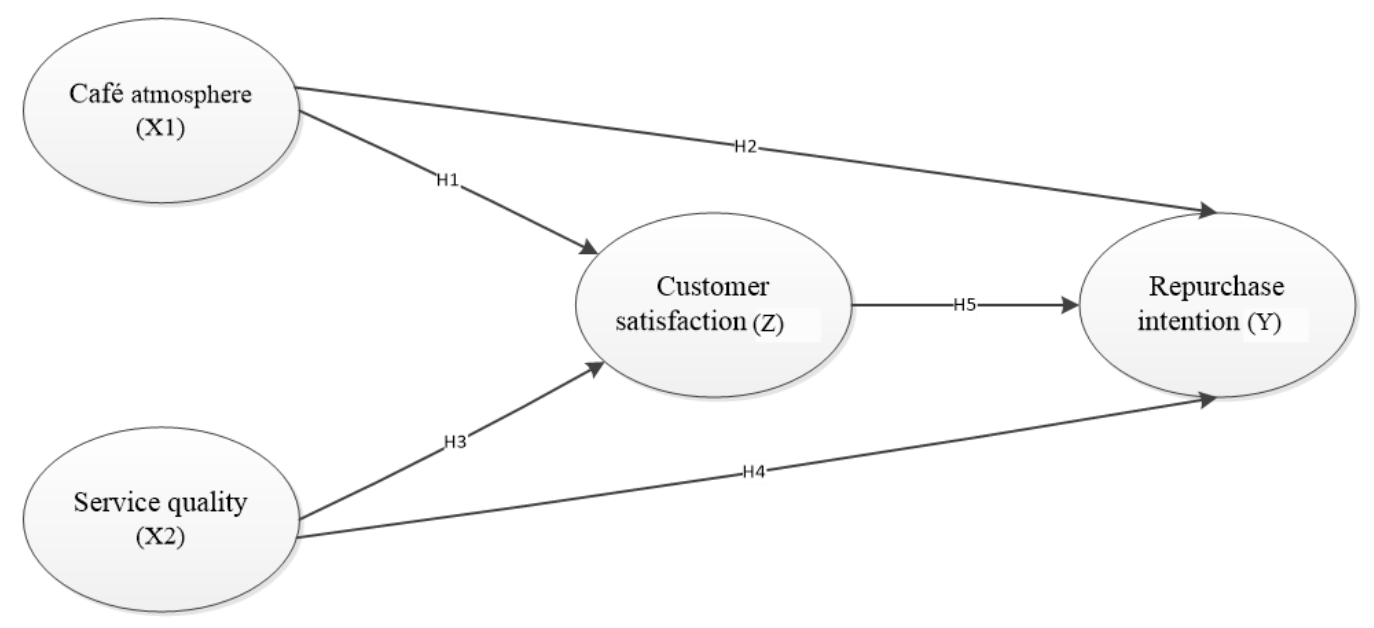

Figure 1. Conceptual Framework

\section{METHODS}

Data collection was done by distributing the questionnaire to consumers of thematic cafes in Surabaya which offer different atmosphere compared to the common cafes. The number of a respondent referred to 10:1 of the number of indicators (Hair et al., 2014), thus there were 150 respondents. Respondent is consumers who have previously ordered a meal in the cafes with a unique atmosphere, which differ from ordinary cafe.

Non-probability sampling with purposive sampling was used as the technique of data collection. It means that the sample taking was based on some characteristics required from the sample (Etikan, Musa, \& Alkassim, 2016; Palys, 2008; Zikmund, Babin, \& Carr, 2009). The questionnaire distributed in those cafes used a 5-point Likert scale, starting from Strongly 
Disagree to Strongly Agree to describe the respondents' answers. Cafe atmosphere and customer satisfaction, for each, were measured using three indicators adapted from Grewal et al. (2003) and Kim et al. (2013) respectively. Service quality was measured using four indicators referring to Ryu et al. (2012). Meanwhile, repurchase intention was measured using five indicators (for instance: "I will return to this thematic cafe in the next time") adapted from Ryu et al. (2012) and Zeithaml, Berry, \& Parasuraman (1996). After that, the data was processed and analyzed using Partial Least Square-Structural Equation Modeling (PLS-SEM) to validate the causal relationship among variables.

\section{RESULT AND DISCUSSION Respondents' Profile}

Based on the result of the descriptive analysis of respondents' profile, it shows that male respondents show a greater number than female respondents $(n=88 ; 59 \%)$. The respondents aged between 14 until $>40$ with the majority of them are $21-30$ years old $(n=86 ; 58 \%)$. The largest number of respondents' education background is High School $(n=84 ; 57 \%)$. Concerning the respondents' job, it is dominated by the private sector $(n=60 ; 40 \%)$.

\section{Outer Model Evaluation}

This stage evaluates the correlation between the construct and its indicators to ensure the validity and reliability of the indicators used in this study. The result of convergent validity test shows that the correlation between construct and latent variable or outer model has met convergent validity since the value of loading factor is not below the required loading factor, that is 0.50 (Hair et al., 2014).

Then, the result of discriminant validity test shows that the value of the loading factor for every indicator from each latent variable has greater loading factor value if it is linked to other latent variables. It means that each latent variable has a good discriminant validity (Hair et al., 2014).

Table 1 presents that all constructs have met reliable criteria. It is shown by the value of composite reliability more than 0.70 and AVE more than 0.50 as the criteria Hair et al. (2014).

\begin{tabular}{ccc}
\multicolumn{3}{c}{ Table 1. Composite Reliability and AVE } \\
\hline Variable & Composite Reliability & AVE \\
\hline X1 & 0.847963 & 0.651067 \\
X2 & 0.817051 & 0.528640 \\
Y & 0.869124 & 0.689396 \\
Z & 0.875583 & 0.590935 \\
\hline
\end{tabular}

\section{Inner Model Evaluation}

The result of R Square Adjusted test (Figure 3) shows that the value of R Square Adjusted for customer satisfaction ( $\mathrm{Y}$ ) is 0.495 and repurchase intention $(\mathrm{Z})$ is 0.652 . It means that $49.5 \%$ of customer satisfaction construct (Y) can be influenced by cafe atmosphere (X1) and service quality (X2) while the remainder is influenced by other constructs which do not examine in this study. In terms of a path model in repurchase intention construct (Z), it is $65.2 \%$. It shows that those three independent constructs substantially describe $65.2 \%$ of variants in repurchase 
Service quality and store atmosphere on customer satisfaction and repurchase intention

intention. In other words, about $65.2 \%$ of repurchase intention change is caused by those three latent constructs in the model.

The coefficient of determination measures the overall effect size and variance explained in the endogenous construct for the structural model and is thus a measure of the model's predictive accuracy. In this study, the inner path model was 0.749 for the quality endogenous latent construct. This indicates that the five independent constructs substantially explain $74.9 \%$ of the variance in the quality, meaning that about $74.9 \%$ of the change in the project quality was due to five latent constructs in the model. According to Hair et al. (2014), an $\mathrm{R}^{2}$ value of 0.75 is considered substantial, an $\mathrm{R}^{2}$ value of 50 is regarded as moderate, and an $\mathrm{R}^{2}$ value of 0.26 is considered as weak. Hence, the $\mathrm{R}^{2}$ value in this study was substantial.

Then, the value of path coefficients is used to describe the correlation among construct hypothesized in the model (Joe et al., 2011). The result of the analysis in Table 2 shows that all hypotheses proposed are supported.

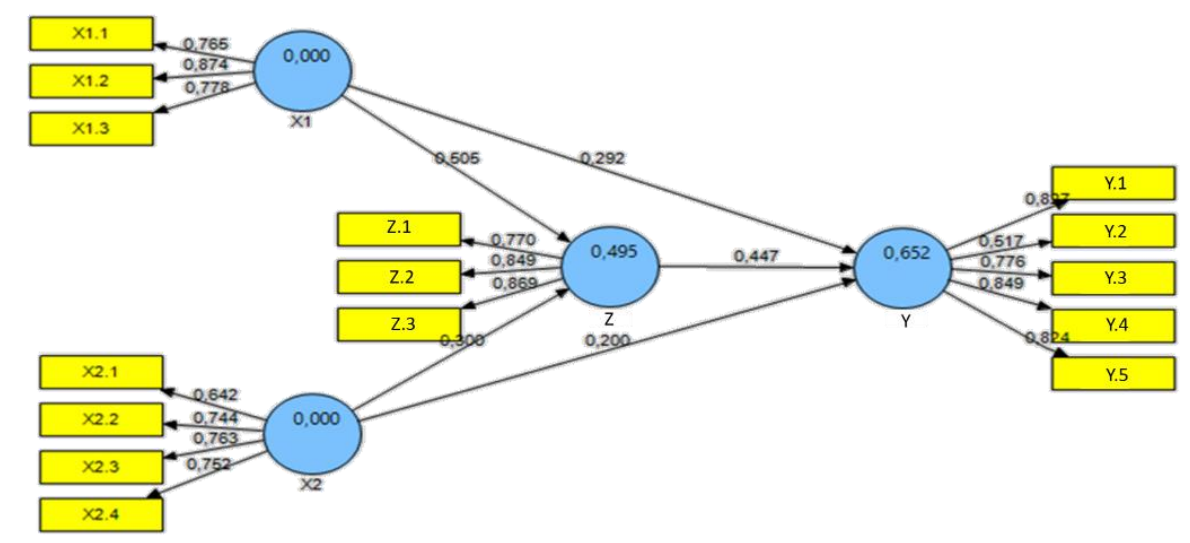

Figure 2. Structural Model

Table 2. Hypothesis Testing

\begin{tabular}{lccccc}
\hline Relationship & $\begin{array}{c}\text { Original } \\
\text { Sample }(\mathrm{O})\end{array}$ & $\begin{array}{c}\text { Sample } \\
\text { Mean }(\mathrm{M})\end{array}$ & $\begin{array}{c}\text { Standard Deviation } \\
(\text { STDEV })\end{array}$ & $\begin{array}{c}\text { T Statistics } \\
(|\mathrm{O} / \mathrm{STERR}|)\end{array}$ & P-Value \\
\hline$(\mathrm{X} 1) \rightarrow(\mathrm{Y})$ & 0.504917 & 0.515690 & 0.096113 & 5.253384 & 0,000 \\
$(\mathrm{X} 1) \rightarrow(\mathrm{Z})$ & 0.517575 & 0.526686 & 0.106767 & 4.847714 & 0,000 \\
$(\mathrm{X} 2) \rightarrow(\mathrm{Y})$ & 0.299987 & 0.300564 & 0.100419 & 2.987343 & 0,003 \\
$(\mathrm{X} 2) \rightarrow(\mathrm{Z})$ & 0.333869 & 0.328513 & 0.092204 & 3.620963 & 0,000 \\
$(\mathrm{Z}) \rightarrow(\mathrm{Y})$ & 0.447288 & 0.446176 & 0.092843 & 4.817691 & 0,000 \\
\hline
\end{tabular}

\section{Discussion}

Based on the data analysis, it can be concluded that the cafe atmosphere has a significant role in customer satisfaction. Thus, H1 is accepted. The servicescape of the cafe enables to influence customer satisfaction towards the service they have been purchased. Intangible nature of service makes the customers have no cues to evaluate their experience in a whole. One of the tangible cues of services that they can observe is the ambience of the cafe. A good cafe atmosphere can be the reason for the customer to assess or evaluate whether they are satisfied with the service given or not. Thereby, a comfortable cafe atmosphere can enhance consumer satisfaction (Nguyen \& Leblanc, 2002; Reimer \& Kuehn, 2005). 
Furthermore, it can be deduced that the cafe atmosphere construct has a significant role in consumer purchase intention in the thematic cafe. Therefore, $\mathrm{H} 2$ is accepted. It infers that a good cafe atmosphere will encourage the customer to repurchase in the cafe. The result of this study is parallel with the previous studies suggesting that cafe atmosphere or ambience is a predictor of customer satisfaction and repeat purchase intention (Ha \& Jang, 2012; Heung \& $\mathrm{Gu}, 2012)$. For the goal of dining out, it is not only to satisfy hunger but also to chill out or to refresh from routine. The ambience of the eatery can affect customers' mood, especially when they consume cafe service for hedonism. Typically, customers who come to the cafe providing unique or specific theme look for the experience and atmosphere which differs from other cafes. Thus, the facility or environment element affects customer satisfaction and determine their repurchase intention (Bitner, 1992).

Based on the testing result of $\mathrm{H} 3$, it can be concluded that service quality construct has a significant influence on customer satisfaction. It means that the third hypothesis in this study is accepted. When getting cafe's service, customers will compare all their experiences based on their expectation and ideal perception of a service. In general, the higher service quality is given, the more customer will be satisfied (Ha \& Jang, 2012; Huang, Lee, \& Chen, 2019; Nietos et al., 2015). Then, it can be inferred that service quality constructs significantly influences the repurchase intention construct. Thereby, the fourth hypothesis in this study is accepted. Service quality is an essential factor to understand customers' behavioural intention. The more customers are satisfied with the service provided, the higher their commitment not to move to another cafe. The satisfied customers will have a higher intention to come back to the cafe compared to the unsatisfied customers. It is in a similar vein with the previous research claiming that service quality is a predictor of consumers' repurchase behaviour in the next time (Baker \& Crompton, 2000; Kim, Park, Choi, \& Jun, 2017; Nietos et al., 2015).

The result of data analysis in this study supports the previous studies asserting that customer satisfaction has a significant role in their repurchase intention (Haemoon, 2000; Han et al., 2009; Kim et al., 2017; Zhang \& Prasongsukarn, 2017). Costumers will be satisfied if the service given is the same as they expect. It will enhance the positive attitude on buying decision in the cafe, so they are not easily going to other cafes. They will go back to repurchase (Huang et al., 2019). Thereby, H5 is accepted.

\section{CONCLUSION}

This study is intended to analyze the influence cafe atmosphere, service quality on customer satisfaction and repurchase intention in thematic cafes in Surabaya. The findings show that the cafe atmosphere and service quality have a significant influence on customer satisfaction in the cafe and intention to go back to the cafe. Furthermore, customer satisfaction also shows a significant influence on customer intention to do repurchasing. Practically, this study may help cafe entrepreneurs to have a better understanding of the important role of cafe atmosphere and service quality to be able to compete in this competitive industry.

One limitation of this study is that the current study only collected data from some cafes in Surabaya, which limits the generalizability of our finding because each region may have a different habit and cultural characteristics. Thus, further research in this field could add other cities in Indonesia as the research sample since socio-cultural diversity can affect the results of 
Soebandhi, S., Wahid, A., \& Darmawanti, I.

Service quality and store atmosphere on customer satisfaction and repurchase intention

each study. It would be also interesting to assess other variables such as perceived value, price, or trust to strengthen customer satisfaction model in shaping customers' repurchase intention.

\section{REFERENCES}

Alma, B. (2011). Manajemen Pemasaran dan Pemasaran Jasa. Bandung: Penerbit Alfabeta.

Andaleeb, S.S. \& Conway, C. (2006). Customer Satisfaction in the Restaurant Industry: An Examination of the Transaction-Specific Model. Journal of Services Marketing, 20(1), 3-11. https://doi.org/10.1108/08876040610646536.

Babin, B.J. \& Attaway, J.S. (2000). Atmospheric Affect as a Tool for Creating Value and Gaining Share of Customer. Journal of Business Research, 49(2), 91-99. https://doi.org/10.1016/S0148-2963(99)00011-9.

Baker, D.A. \& Crompton, J.L. (2000). Quality, Satisfaction and Behavioral Intentions. Annals of Tourism Research, 27(3), 785-804. https://doi.org/10.1016/S0160-7383(99)00108-5.

Berman, B.R. \& Evans, J.R. (2013). Retail Management: A Strategic Approach (12th ed.). New Jersey, USA: Palgrave Macmillan.

Bitner, M. J. (1992). Servicescapes: The Impact of Physical Surroundings on Customers and Employees. Journal of Marketing, 56(2), 57-71. https://doi.org/10.2307/1252042.

Byon, K. K., Zhang, J. J., \& Baker, T. A. (2013). Impact of Core and Peripheral Service Quality on Consumption Behavior of Professional Team Sport Spectators as Mediated by Perceived Value. European Sport Management Quarterly, 13(2), 232-263. https://doi.org/0.1080/16184742.2013.767278.

Chang, K. (2000). The Impact of Perceived Physical Environments on Customers' Satisfaction and Return Intentions. Journal of Professional Services Marketing, 21(2), 75-85. https://doi.org/10.1300/J090v21n02_06.

Chow, I. H. S, Lau, V. P., Lo, T. W. C., Sha, Z., \& Yun, H. (2007). Service Quality in Restaurant Operations in China: Decision- and Experiential-Oriented Perspectives. International Journal of Hospitality Management, 26(3), 698-710. https://doi.org/10.1016/j.ijhm.2006.07.001.

Cox, R. \& Brittain, P. (2004). Retailing an Introduction (5 ed.). England: Pearson Education Limited.

Etikan, I. Musa, S.A., \& Alkassim, R.S. (2016). Comparison of Convenience Sampling and Purposive Sampling. American Journal of Theoretical and Applied Statistics, 5(1), 1-4. https://doi.org/10.11648/j.ajtas.20160501.11.

Grewal, D., Baker, J., Levy, M., \& Voss, G.B. (2003). The Effects of Wait Expectations and Store Atmosphere Evaluations on Patronage Intentions in Service-Intensive Retail Stores. Journal of Retailing, 79(4), 259-268. https://doi.org/10.1016/j.jretai.2003.09.006.

Ha, J. \& Jang, S. (2012). The Effects of Dining Atmospherics on Behavioral Intentions through Quality Perception. Journal of Services Marketing, 26(3), 204-215. https://doi.org/10.1108/08876041211224004. 
Haemoon, O. (2000). Diners' Perceptions of Quality, Value, and Satisfaction: A practical Viewpoint. The Cornell Hotel and Restaurant Administration Quarterly, 41(3), 58-55. https://doi.org/10.1016/S0010-8804(00)80017-8.

Hair, J. F., Hult, G. T. M., Ringle, C. M., \& Sarstedt, M. (2014). A Primer on Partial Least Squares Structural Equation Modeling (PLS-SEM). Thousand Oaks: Sage.

Hair, J. F., Ringle, C. M., \& Sarstedt, M. (2011). PLS-SEM: Indeed a Silver Bullet. Journal of Marketing Theory and Practice, 19(2), 139-152. https://doi.org/10.2753/MTP10696679190202.

Han, H., Back, K. J., \& Barrett, B. (2009). Influencing Factors on Restaurant Customers' Revisit Intention: The Roles of Emotions and Switching Barriers. International Journal of Hospitality Management, 28(4), 563-572. https://doi.org/10.1016/j.ijhm.2009.03.005.

Han, S. L., \& Hong, S. T. (2005). Effects of Service Quality on Customer Retention and WordOf-Mouth in a Retail Setting: Comparative Study of Different Scales. AP - Asia Pacific Advances in Consumer Research, Duluth, MN. https://www.acrwebsite.org/volumes/11923/volumes/ap06/AP-06.

Hasan, A. (2013). Marketing Dan Kasus Kasus Pilihan. Yogyakarta: CAPS (Center For Academic Publishing Service).

Heung, V. C. S., \& Gu, T. (2012). Influence of Restaurant Atmospherics on Patron Satisfaction and Behavioral Intentions. International Journal of Hospitality Management, 31(4), 1167-1177. https://doi.org/10.1016/j.ijhm.2012.02.004.

Huang, P. L., Lee, B. C. Y., \& Chen, C. C. (2019). The Influence of Service Quality on Customer Satisfaction and Loyalty In B2b Technology Service Industry Total Quality Management \& Business Excellence, 30(13-14), 1449-1465. https://doi.org/10.1080/14783363.2017.1372184.

JPNN. (2018). Restoran di Surabaya Tumbuh 20\% per Tahun. Retrieved 1 December 2019 from https://www.jpnn.com/news/restoran-di-surabaya-tumbuh-20-persen-per-tahun.

Keyt, J. C., Yavas, U., \& Riecken, G. (1994). Importance-Performance Analysis: A Case Study in Restaurant Positioning. International Journal of Retail \& Distribution Management, 22(5), 35-40. https://doi.org/10.1108/09590559410067325.

Kim, H.J., Park, J., Kim, M. J., \& Ryu, K. (2013). Does Perceived Restaurant Food Healthiness Matter? Its Influence On Value, Satisfaction and Revisit Intentions in Restaurant Operations in South Korea International Journal of Hospitality Management, 33, 397405. https://doi.org/10.1016/j.ijhm.2012.10.010.

Kim, W., Park, H. S., Choi, W., \& Jun, H. (2017). The Relationships between Service Quality, Satisfaction, and Purchase Intention of Customers at Non-Profit Business. International Journal of Business Marketing and Management, 2(1), 12-19.

Kivela, J., Inbakaran, R., \& Reece, J. (2000). Consumer Research in the Restaurant Environment. Part 3: Analysis, Findings and Conclusions. International Journal of $\begin{array}{llrr}\text { Contemporary Hospitality 13-30. } & \text { Manement, }\end{array}$ https://doi.org/10.1108/09596110010304984. 
Service quality and store atmosphere on customer satisfaction and repurchase intention

Kotler, P. (1973). Atmospherics as a Marketing Tool. Journal of Retailing, 49(4), 48.

Kristiana, M., \& Edwar, M. (2017). Pengaruh Store Atmosphere dan Kualitas Layanan terhadap Kepuasan Konsumen Cafe Heerlijk Gelato Perpustakaan Bank Indonesia Surabaya. Jurnal Pendidikan Tata Niaga (JPTN), 1(1).

Laroche, M., Ueltschy, L. C., Abe, S., Cleveland, M., \& Yannopoulos, P.P. (2004). Service Quality Perceptions and Customer Satisfaction: Evaluating the Role of Culture. Journal of International Marketing, 12(3), 58-85.

Lin, I. Y. (2009). The Combined Effect of Color and Music on Customer Satisfaction in Hotel Bars. Journal of Hospitality Marketing \& Management, 19(1), 22-37. https://doi.org/10.1080/19368620903327675.

Market Access Secretariat Global Analysis Report. (2016). Foodservice Profile Indonesia. Retrieved 1 December 2019 from http://www.agr.gc.ca/resources/prod/InternetInternet/MISB-DGSIM/ATS-SEA/PDF/6769-eng.pdf.

Mordor Intelligence. (2018). Indonesia Foodservice Market Size - Segmented by Type (FullService Restaurants, Quick-Service Restaurants, Cafes/Bars, 100\% Home Delivery) and Structure (Chained Restaurants and Independent Restaurants) - Growth, Trends and Forecast (2018 - 2023). Retrieved 1 December 2019 from https://www.mordorintelligence.com/industry-reports/indonesia-foodservice-market.

Namkung, Y., \& Jang, S. (2007). Does Food Quality Really Matter in Restaurants? Its Impact On Customer Satisfaction and Behavioral Intentions. Journal of Hospitality \& Tourism Research, 31(3), 387-409. https://doi.org/10.1177/1096348007299924.

Nguyen, N. \& Leblanc, G. (2002). Contact Personnel, Physical Environment and the Perceived Corporate Image of Intangible Services by New Clients. International Journal of Service Industry Management, 13(3), 242-262. https://doi.org/10.1108/09564230210431965.

Nietos, I.F., Zournatzi, E., Koustelios, A., \& Costa, G. (2015). Relationship among Service Quality, Customer Satisfaction, and Renewal Intentions in Recreation Theme Park in Greece. International Journal of Sport Management, Recreation \& Tourism, 18. 41-55.

Palys, T. (2008). Purposive Sampling. In L. M. Given (Ed.), The SAGE Encyclopedia of Qualitative Research Methods (Vol. 1 \& 2, pp. 697-698). Thousand Oaks, CA: Sage.

Parasuraman, A., Zeithaml, V., \& Berry, L. (1988). SERVQUAL: A Multiple-Item Scale for Measuring Consumer Perceptions of Service Quality. Journal of Retailing, 64(1), 12-40.

Peter, J. P., \& Olson, J. C. (2010). Consumer Behavior \& Marketing Strategy. New York: McGraw-Hill Irwin.

Reimer, A. \& Kuehn, R. (2005). The Impact of Servicescape on Quality Perception. European Journal of Marketing, 39(7/8), 785-808. https://doi.org/10.1108/03090560510601761.

Ryu, K., Lee, H. R., \& Gon, K. W. (2012). The Influence of the Quality of the Physical Environment, Food, and Service on Restaurant Image, Customer Perceived Value, Customer Satisfaction, and Behavioral Intentions. International Journal of 
Contemporary Hospitality Management, 200-223. https://doi.org/10.1108/09596111211206141.

Schnaars, S. P. (1991). Marketing Strategy: A Customer Driven Approach. New York, USA: The Free Press.

Sirgy, M. J., Grewal, D., \& Mangleburg, T. (2000). Retail Environment, Self-Congruity, and Retail Patronage: An Integrative Model and a Research Agenda. Journal of Business Research, 49(2), 127-138. https://doi.org/10.1016/S0148-2963(99)00009-0.

Söderlund, M. \& Vilgon, M. (1999). Customer Satisfaction and Links to Customer Profitability: An Empirical Examination of the Association between Attitudes and $\begin{array}{lllll}\text { Behavior. } & \text { Retrieved } & 1 & \text { Desember } & 2019 \text { from }\end{array}$ https://EconPapers.repec.org/RePEc:hhb:hastba:1999_001.

Soriano, D. R. (2002). Customers' Expectations Factors in Restaurants: The Situation in Spain. International Journal of Quality \& Reliability Management, 19(8/9), 1055-1067. https://doi.org/10.1108/02656710210438122.

Tambunan, P. R. \& Suryawardani, B. (2015). Pengaruh Kualitas Pelayanan terhadap Kepuasan Pelanggan pada PT. JNE Perwakilan Kawaluyaan Tahun 2014. Banking and Management Review, 4(2), 2252-8520.

Tan, Y. (2019). Pengaruh Service Quality Terhadap Repurchase Intention dengan Customer Satisfaction sebagai Variabel Intervening pada PT Bank Central Asia Tbk. Studi Kasus KCU Darmo Surabaya. Jurnal Strategi Pemasaran, 6(1).

Tjiptono, F. \& Chandra, G. (2013). Pemasaran Strategik (2 ed.). Yogyakarta: Penerbit Andi.

Venetis, K. A., \& Ghauri, P. N. (2004). Service Quality and Customer Retention: Building Long-Term Relationships. European Journal of Marketing, 38(11/12), 1577-1598. https://doi.org/10.1108/03090560410560254.

Zeithaml, V. A., Berry, L. L., \& Parasuraman, A. (1996). The Behavioral Consequences of Service Quality. Journal of Marketing, 60, 31-46.

Zhang, Q. \& Prasongsukarn, K. (2017). A Relationship Study of Price Promotion, Customer Quality Evaluation, Customer Satisfaction and Repurchase Intention: A Case Study of Starbucks in Thailand. International Journal of Management and Applied Science, 3(9), 29-32.

Zikmund, W. G., Babin, B. J., \& Carr, J. C. (2009). Business Research Methods (8th ed.): Boston, New England: South-Western Cengage Learning. 